\title{
Distribution and Important Areas for the Conservation of Amphibians in the Province of Seville, Spain: Identifying Priorities
}

\author{
Eduardo José Rodríguez-Rodríguez ${ }^{1, * \mathbb{D}}$ and Rafael Carmona-González ${ }^{2}$ \\ 1 Department of Integrated Sciences (Biology), Faculty of Experimental Sciences, Campus el Carmen, \\ University of Huelva, Avda Tres de Marzo SN, 21007 Huelva, Spain \\ 2 Independent Researcher, 41010 Seville, Spain; rafacarmona94@hotmail.es \\ * Correspondence: eduardo.rodriguez@dci.uhu.es
}

check for updates

Citation: Rodríguez-Rodríguez, E.J.; Carmona-González, R. Distribution and Important Areas for the

Conservation of Amphibians in the

Province of Seville, Spain: Identifying Priorities. Hydrobiology 2022, 1, 39-46. https://doi.org/10.3390/

hydrobiology1010004

Academic Editor:

Adolfo Cordero-Rivera

Received: 8 November 2021

Accepted: 30 November 2021

Published: 3 December 2021

Publisher's Note: MDPI stays neutral with regard to jurisdictional claims in published maps and institutional affiliations.

Copyright: (c) 2021 by the authors. Licensee MDPI, Basel, Switzerland. This article is an open access article distributed under the terms and conditions of the Creative Commons Attribution (CC BY) license (https:// creativecommons.org/licenses/by/ $4.0 /)$.

\begin{abstract}
Amphibians are among the most threatened vertebrates in the world due to habitat destruction, emerging diseases, and climate change, and therefore, it is of critical importance to identify the risk and conservation measures for their populations. In this work, we aimed to identify the status of amphibian distribution in the province of Seville, in the south of Spain. We additionally wanted to identify critical conservation areas and propose measures of conservation for the whole community as well as specific taxa. To do this, we mapped the distribution of amphibians using our own data and bibliography and translated it into a $10 \times 10 \mathrm{~km}^{2}$ UTM grid. Our work has allowed us to identify several areas of importance for amphibians in the province and populations of some species that need special attention.
\end{abstract}

Keywords: amphibians; distribution; conservation; priorities; important areas

\section{Introduction}

Amphibians are among the most threatened vertebrates in the world due to habitat destruction [1], emerging diseases such as chytridiomicois or ranavirus [2], climate change [3], and pollution [4]. These risks could be more intense in Mediterranean ecosystems due to the severe impact of the mentioned changes to climate and habitat, as found in a recent study in the western Mediterranean [3]. In fact, more than a third of global amphibian species are threatened and their genetic diversity loss is accelerating extinction [4]. For this reason, the identification of conservation priorities regarding areas, species, and populations is crucial, even at a local scale. The first stage in this strategy is to provide comprehensive knowledge about the current distribution, allowing us to identify the mentioned conservation priorities. Once this is achieved, necessary corrections and other conservation actions can be undertaken.

Seville is a province of Spain located in the Andalusia region at the south of the Iberian Peninsula (see Figure 1). It occupies $14,042 \mathrm{~km}^{2}$ and is distributed among $18510 \times 10 \mathrm{~km}^{2}$ UTM squares-91 are fully included in the province and the rest are shared with other provinces or fragmented by the change of geographic zones (29 and 30) that cross the province from north to south. The weather is typical of the Mediterranean, with a mean pluviometry of $576 \mathrm{~mm}$ and thermomediterranean and mesomediterranean bioclimatic floors [5]. The province is crossed by two mountain ranges, the Sierra Morena in the north and the Sierra Sur (part of the Betic Mountain Range) in the south, separated by the Guadalquivir Valley. The medium altitude is $200 \mathrm{msnm}$, and the maximum altitude is in the Betic mountains (Terril peak, $1128 \mathrm{msnm}$ ). In Sierra Morena, the lithology is predominantly metamorphic, whereas, in Sierra Sur, it is limestone. The Guadalquivir Valley is an alluvial plain highly anthropized by agricultural activity, although a small number of cleared forest patches remain. In this area, there are several remarkable endorheic complexes, such as 
Lantejuela, Utrera, and Lebrija, Las Cabezas. Located near the Guadalquivir mouth is Doñana National Park, a valuable natural area of marshes, forests, coastal dunes, and freshwater temporal lagoons. The north mountain range is mostly forested, with a mixture of forest with scrub and cleared forest with livestock and hunting activity, whereas in the south mountain range, we found a mixture of scrub and forest with crops. The main river course, the Guadalquivir, has important tributaries at the ecological level, especially in the right margin. It originates in the north mountain range (Sierra Morena) and has small basins and marked seasonality. In the left margin, there are tributaries with greater flow but a worse state of conservation.

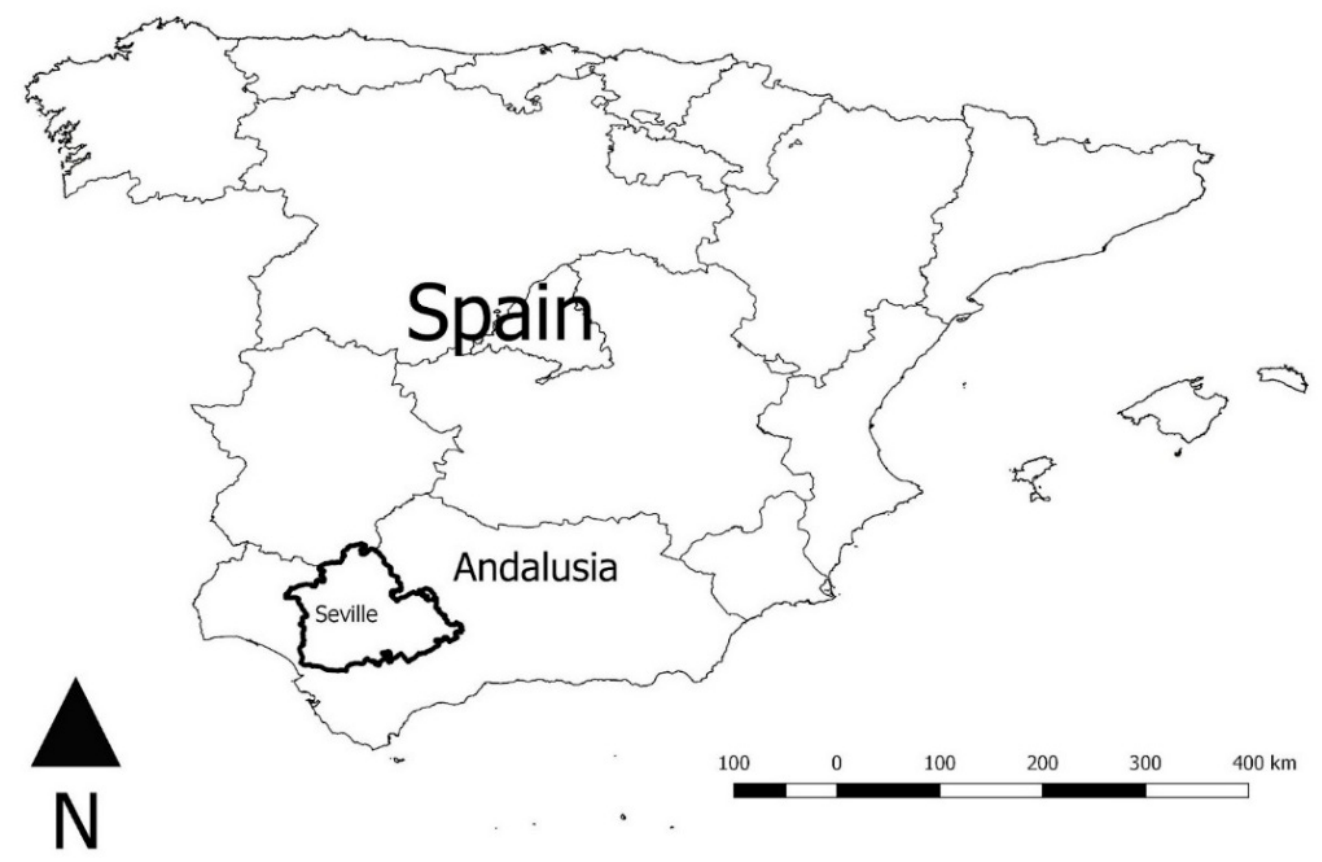

Figure 1. Location of Seville province in Spain.

The first work regarding amphibians in the province is from 1859; Erpetologia Hispalensis, Catalogus Methodicus Reptilium et Amphibiorum was written by Antonio Machado Núñez. Later, some works such as those written by Pleguezuelos [6,7] greatly contributed to the knowledge of the distribution of amphibians within the province. The SIARE platform from the Spanish Herpetological Association maintains continuous updates, although without data purification. Vries et al. [8] generated valuable data and comprehensive distribution knowledge about amphibians within the limits of Sierra Norte de Sevilla Natural Park. More recently, Rodríguez-Rodríguez et al. [9] updated the information regarding the distribution of reptiles in the province, not including amphibians. Finally, Salvador et al. [10] provided an overview of the distribution in Spain, but without detail at the provincial level.

The aim of this work was to provide a detailed update of the distribution of amphibians in the province of Seville, including species richness patterns around the territory, with the objective of laying the foundation for the planning of present and future conservation.

\section{Materials and Methods}

To collect the data, we used two sources of information. First, we surveyed each $10 \times 10 \mathrm{~km}^{2}$ UTM square of the province, looking for water points as possible reproduction areas in the two periods of maximum activity, autumn and spring. The survey period was scheduled from 2015 to 2021, during nighttime hours and humid weather, to facilitate the detectability of these organisms. As this study was based on distribution, only visual surveys were implemented, excluding the manipulation of animals to avoid the unnecessary risk of emergent disease transmissions between populations [11]. 
Additionally, we have complemented this information with the data compiled from the bibliography, including reports from SIARE [12] and Pleguezuelos et al. [7]. As SIARE is a collaborative platform, we have revised the data for the detection of possible errors, discarding those that we can consider evident.

All the information has been mapped using QGIS [13], and differencing was confirmed by the authors and bibliographic data prior to 2015. We also calculated the species richness for each $10 \times 10 \mathrm{~km}^{2}$ UTM and analyzed the total of these UTMs occupied by each species. With this, we aimed to identify priority areas and species for conservation.

\section{Results}

Twelve species were detected in the province (Figure 2 and Table 1)—four urodeles (Salamandra salamandra, Triturus pygmaeus, Lissotriton boscai, and Pleurodeles waltl) and eight anurans (Epidalea calamita, Bufo spinosus, Discoglossus galganoi, Alytes cisternasii, Pelobates cultripes, Pelodytes ibericus, Pelophylax perezi, and Hyla meridionalis). It is important to note that Hyla molleri has been reported in some past sources, such as The Atlas and Red Book of the Reptiles and Amphibians of Spain (Pleguezuelos et al., 2002), although no evidence of this species was found in the province despite an intensive search in the suspected historical areas.

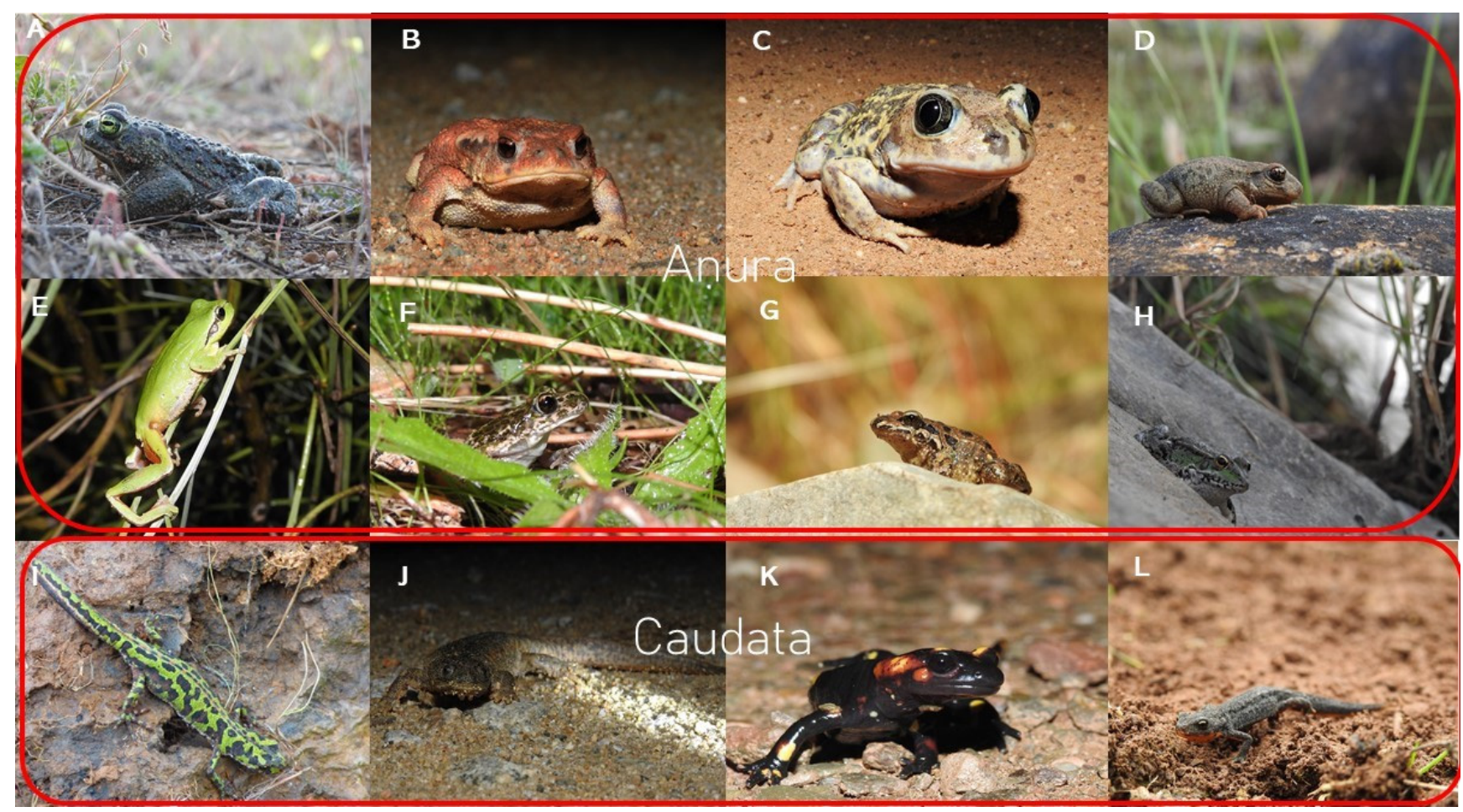

Figure 2. Amphibians detected in the province of Seville. (A) Epidalea calamita; (B) Bufo spinosus; (C) Pelobates cultripes; (D) Alytes cisternasii; (E) Hyla meridionalis; (F) Pelodytes ibericus; (G) Discoglossus galganoi; (H) Pelophylax perezi; (I) Triturus pygmaeus; (J) Pleurodeles waltl; (K) Salamandra salamandra; (L) Lissotriton boscai. Pictures by Rodríguez-Rodríguez, E.J. 
Table 1. Breeding habitat and periods (inside Seville province) for the twelve detected species. Common names also provided.

\begin{tabular}{cccc}
\hline Species & Common Name & Typical Breeding Habitat & $\begin{array}{c}\text { Breeding Period } \\
\text { (Study Area) }\end{array}$ \\
\hline Alytes cisternassi & Iberian midwife toad & Streams & Autumn \\
\hline Bufo spinosus & Spiny common toad & Streams and rafts & Spring \\
\hline Epidalea calamita & Natterjack & Shallow puddles and ponds & Late winter and spring \\
\hline Pelodytes ibericus & Iberian parsley frog & Shallow ponds, freshwater marshes & Winter \\
\hline Discoglossus galganoi & Iberian painted frog & Shallow puddles and ponds & Spring \\
\hline Pelobates cultripes & Western spadefoot & Ponds with long hydroperiod & Spring \\
\hline Hyla merdionalis & Mediterranean tree frog & Ponds with long hydroperiod & Late winter/spring \\
\hline Pelophylax perezi & Perez's frog & Very general & Late spring/summer \\
\hline Lissotriton boscai & Bosca's newt & Stream pools and artificial pools & Spring \\
\hline Triturus pygmaeus & Southern marbled newt & Stream pools and artificial pools & Spring \\
\hline Pleurodeles walt & Iberian ribbed newt & Ponds with long hydroperiod and pools & Spring \\
\hline Salamandra salamandra & Fire salamander & Streams & Autumn \\
\hline
\end{tabular}

Distribution maps for each species $\left(10 \times 10 \mathrm{~km}^{2}\right.$ UTM squares) are provided in Figure 3, and the total number of squares occupied by each species is in Figure 4. As can be observed, the most distributed species in the province is Pelophylax perezi (184 squares), followed by Pleurodeles waltl and Hyla meridionalis (with 128 and 109 squares, respectively). The species with a narrower distribution are the newts, Triturus pygmaeus and Lissotriton boscai (40 and 42 squares respectively). We can also observe that Salamandra salamandra is restricted to both mountain ranges (north and south).

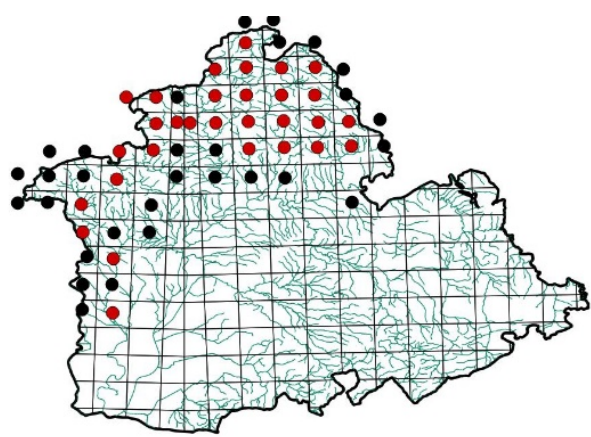

Alytes cisternassi

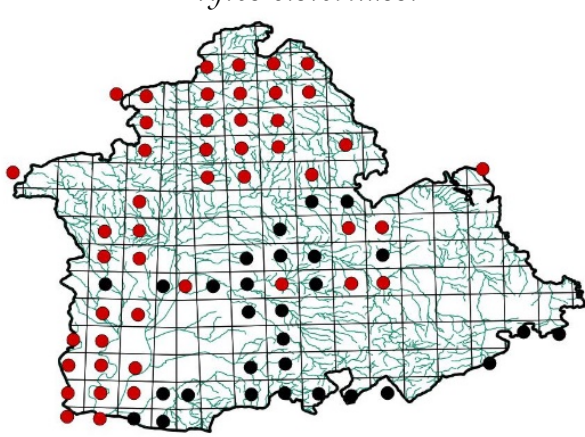

Pelodytes ibericus

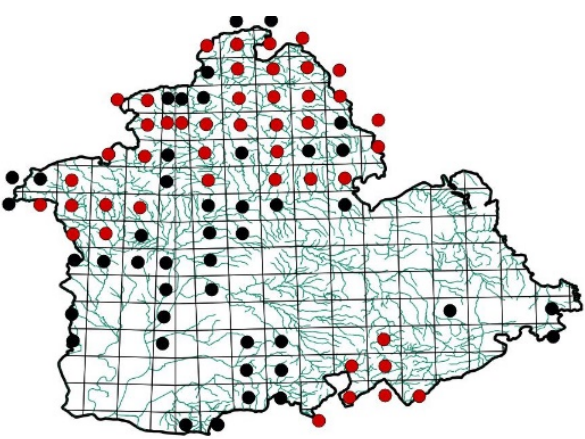

Bufo spinosus

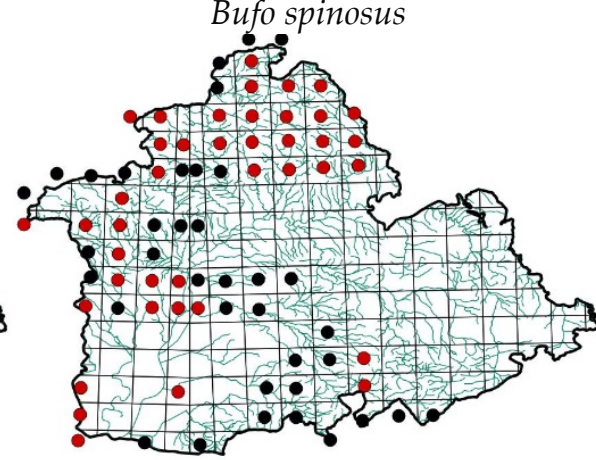

Discoglossus galganoi

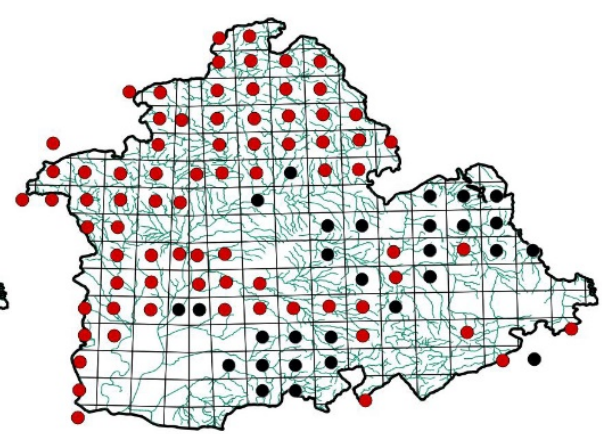

Epidalea calamita

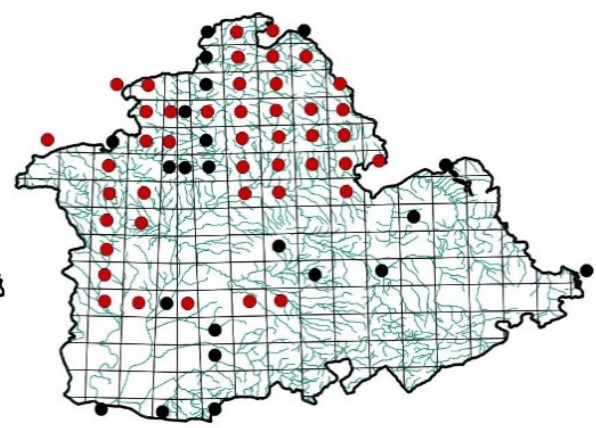

Pelobates cultripes

Figure 3. Cont. 


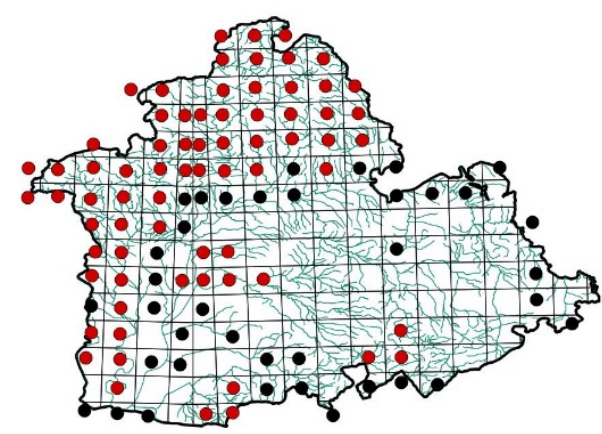

Hyla merdionalis

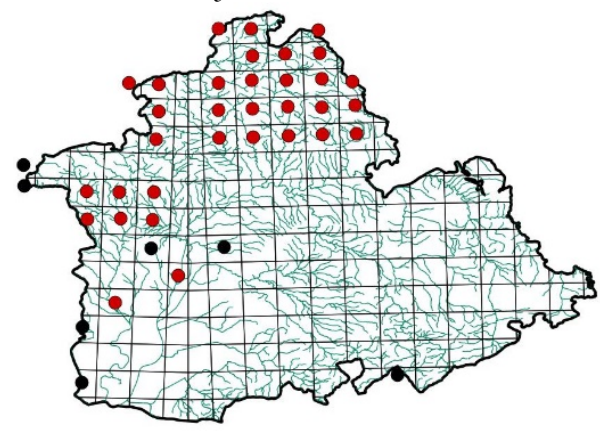

Triturus pygmaeus

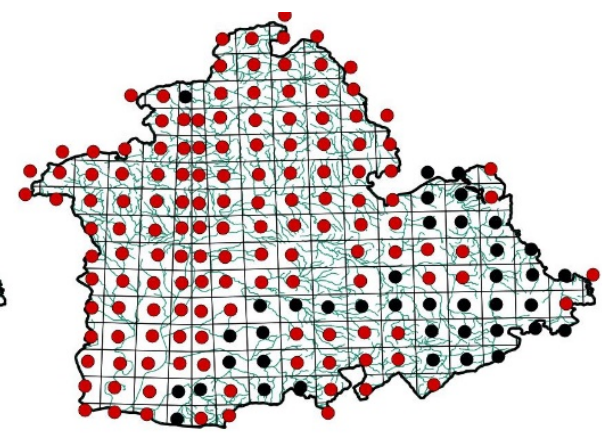

Pelophylax perezi

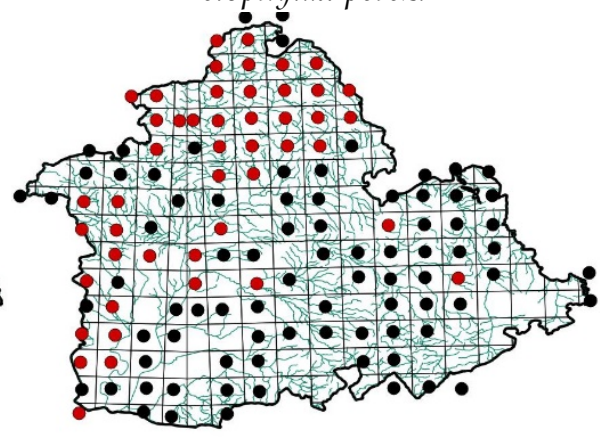

Pleurodeles waltl

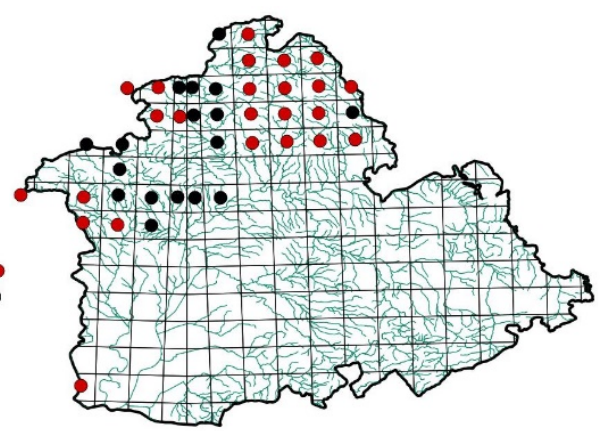

Lissotriton boscai

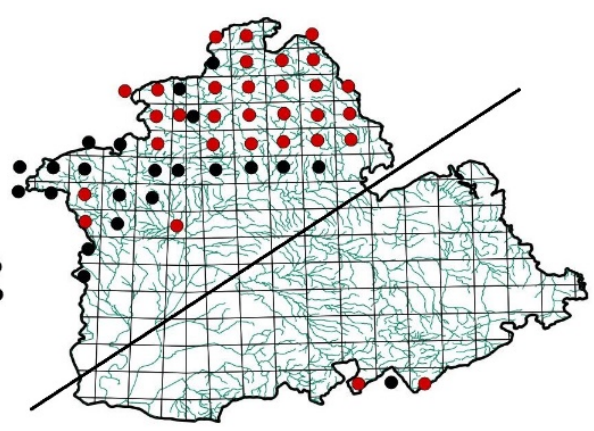

Salamandra salamandra

Figure 3. Distribution map for the twelve amphibian species detected in Seville province. Note that Salamandra salamandra presents two subspecies in this territory. Hydrography also shown in the maps. Red dots indicate confirmed by authors new data (after 2015), and black dots bibliographical data prior to 2015.

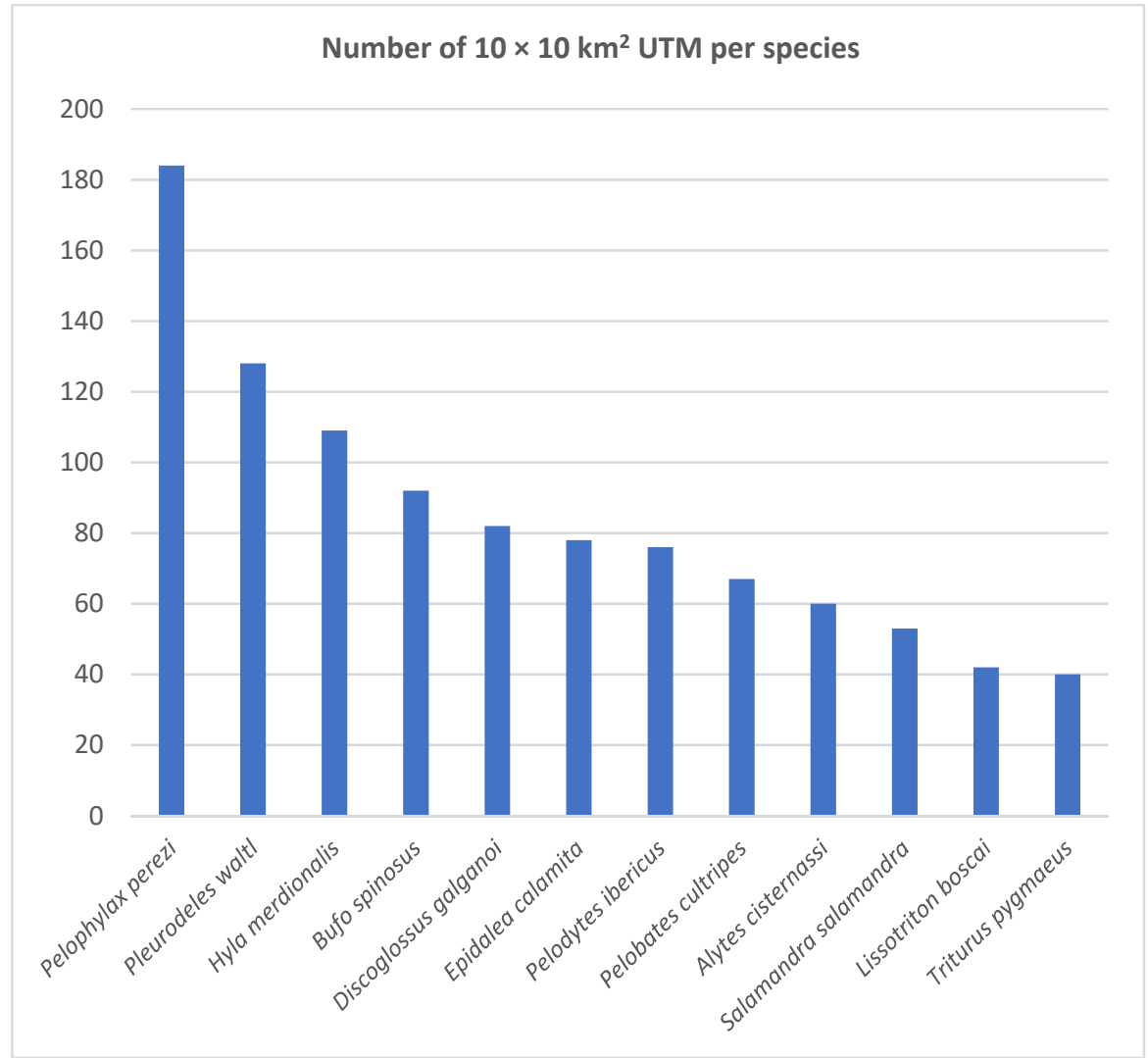

Figure 4. Number of $10 \times 10 \mathrm{~km}^{2} \mathrm{UTM}$ occupied by each species. 
Regarding the species richness in each UTM square, the results are shown in Figure 5. The areas with maximum values of richness are in the north and northwest of the province, both areas of the Sierra Morena region, and coincide with Sierra Norte de Sevilla Natural Park and several Natura 2000 network areas, noting, for example, Madroñalejo (Special Conservation Areas, SAC) in the La Plata region. However, not with the maximum values, but with an important number of species, we can find the south mountain range (Sierra Sur in the Betic range) and the west of the province coincide with the periphery of Donana National Park, some Natura 2000 areas, and other regional conservation areas. The lowest values were found in the Guadalquivir Valley, an area covered by agricultural activities.
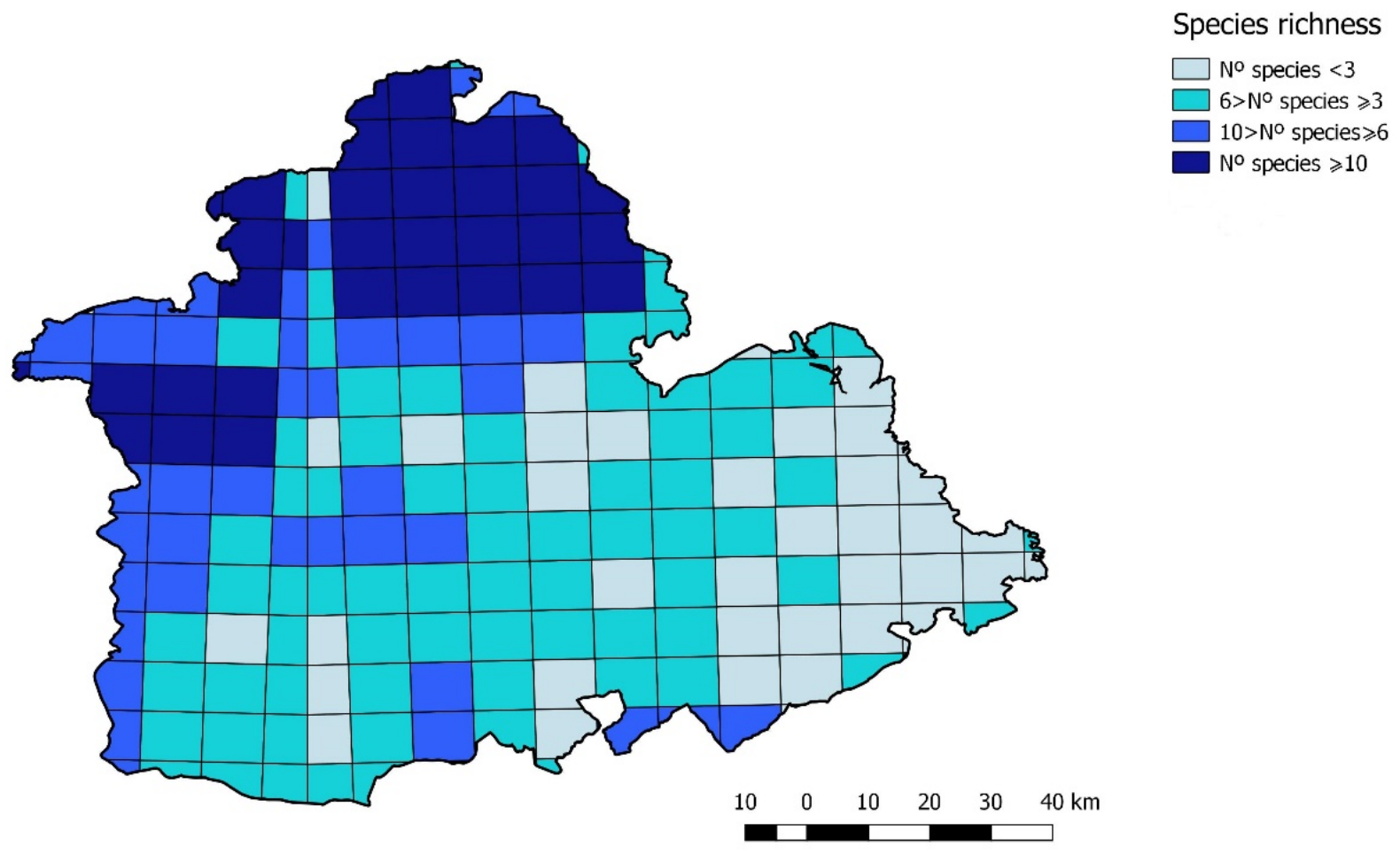

Figure 5 . Species richness by $10 \times 10 \mathrm{~km}^{2} \mathrm{UTM}$ square.

\section{Discussion}

According to our results, Seville province maintains a rich community of amphibians in some areas (compared with other regions in the south of Spain [14,15]), like both mountain ranges (Sierra Morena and Sierra Sur) and the west of the province, whereas the Guadalquivir Valley presents a degraded community of this group, with a reduced number of species and abundance. Although it is possible that some species have been not detected in these squares, considering that all of them were surveyed, it is clear that if they are present, they must be in extremely low densities. This fact can be explained by the agricultural historic transformation and recent intensification coinciding with the loss of water breeding points. It is also important to remark that survey effort and knowledge in these areas could be lower than in better preserved areas, but in any case, it is likely that the diversity of amphibians in these agricultural landscapes has been heavily reduced, as reported by Ruso et al. [16], especially if we compare it with the north of the province.

Regarding the identification of important areas for conservation, it seems that the entire Sierra Morena region in the north, including Sierra Norte de Sevilla Natural Park (as previously identified by Vries et al. [8]), and the La Plata region are the higher priorities. However, we also found important areas with still acceptable amphibian communities (compared with other regions of Seville and other provinces) [14,15], in the west of the province, especially in Doñana National Park and its periphery, and the south mountain range (Sierra Sur). 
We propose, in addition to preserving the identified important areas, to implement measures to improve the health of amphibian communities in these areas where, currently, they are more degraded. Measures like the protection of natural habitat patches and, especially, water breeding points, are essential, as is the creation of new water points, like temporary ponds not far from where populations are detected, in order to increase the resiliency of these and increase expansion and colonization. To achieve this, a detailed breeding point mapping of these areas is a basic preliminary task to develop an efficient strategy.

Finally, we can mention specific proposed measures for the lowest distributed species, such as Triturus pygmaeus. In this case, the population in the north of the province is healthy, not only regarding its distribution but also in abundance. However, the populations in the west of the province are scattered and isolated, with low population densities and involving a higher risk of genetic diversity loss [4]. This is a consequence of the agricultural intensification and the direct destruction of breeding points in these areas [17], less abrupt than the mountain ranges and, thus, more sensitive to human impacts. Additionally, all known populations in this area have a high rate of reproductive failure, as breeding points remain in an inadequate hydroperiod most years, reducing recruitment. Therefore, it is crucial that these remaining sites are protected, like those present in the Doñana Norte y Oeste SAC area and other Aljarafe localities. The creation of new artificial breeding habitats with the capacity for retaining an adequate hydroperiod is also an important measure to increase densities and encourage connectivity. On the other hand, Lissotriton boscai has reduced distribution in the province, but it is still abundant where it is present. Salamandra salamandra has two subspecies in the province-Salamandra salamandra morenica and Salamandra salamandra longirostris. The first one is relatively well distributed in the north of the province (north mountain range, Sierra Morena), but Salamandra salamandra longirostris is very sensitive to extinction in the province. A few populations were detected during our surveys, but with only regular annual breeding in one of them, the rest being records of a few adult individuals observed in the road. These sensible populations are at the north distributional border, and we consider it necessary to avoid the contraction of the occupied area in order to improve the resilience of the entire subspecies population.

To summarize, our proposal for the conservation of amphibians in the province includes the intensive protection of the priority areas mentioned, the improvement of habitat in areas where amphibian communities are degraded, and intense vigilance and recovery action of critical populations such as Triturus pygmaeus in the west and Salamandra salamandra longirostris in the south. Of course, it is of critical importance to prevent the spread of amphibian diseases, such as Chytridiomycosis (both the one produced by Batrachochytrium dendrobatidis and the one produced by Batrachochytrium salamandrivorans) or ranavirus $[18,19]$.

Author Contributions: Data collection, E.J.R.-R. and R.C.-G., conceptualization, E.J.R.-R. and R.C.-G.; methodology, E.J.R.-R.; software, E.J.R.-R.; writing, E.J.R.-R.; review and editing, R.C.-G. All authors have read and agreed to the published version of the manuscript.

Funding: This research received no external funding.

Institutional Review Board Statement: Not applicable as surveys were only visual, without any animal manipulation.

Informed Consent Statement: Not applicable.

Data Availability Statement: Due to the vulnerability of these populations, data generated by authors is available under motivated request.

Acknowledgments: We want to acknowledge the editorial board for the invitation to publish in this inaugural volume.

Conflicts of Interest: The authors declare no conflict of interest. 


\section{References}

1. Cushman, S.A. Effects of habitat loss and fragmentation on amphibians: A review and prospectus. Biol. Conserv. 2006, 128, 231-240. [CrossRef]

2. Martel, A.; Spitzen-van der Sluijs, A.; Blooi, M.; Bert, W.; Ducatelle, R.; Fisher, M.C.; Woeltjes, A.; Bosman, W.; Chiers, K.; Bossuyt, F.; et al. Batrachochytrium sala-mandrivorans sp. nov. causes lethal chytridiomycosis in amphibians. Proc. Natl. Acad. Sci. USA 2013, 110, 15325-15329. [CrossRef] [PubMed]

3. Rodríguez-Rodríguez, E.J.; Beltrán, J.F.; El Mouden, E.H.; Slimani, T.; Márquez, R.; Donaire-Barroso, D. Climate change challenges IUCN conservation priorities: A test with western Mediterranean amphibians. SN Appl. Sci. 2020, 2, 1-11. [CrossRef]

4. Fasola, E.; Ribeiro, R.; Lopes, I. Microevolution due to pollution in amphibians: A review on the genetic erosion hypothesis. Environ. Pollut. 2015, 204, 181-190. [CrossRef] [PubMed]

5. REDIAM. Red de Información Ambiental de Andalucía. Consejería de Agricultura, Ganadería, Pesca y Desarrollo Sostenible. Junta de Andalucía. 2020. Available online: https:/ / laboratoriorediam.cica.es/VisorRediam/ (accessed on 29 October 2021).

6. Pleguezuelos, J.M. Distribución y Biogeografía de los Anfibios y Reptiles de España y Portugal; Universidad de Granada: Granada, Spain, 1997.

7. Pleguezuelos, J.M.; Márquez, R.; Lizana, M. Atlas y Libro Rojo de los Anfibios y Reptiles de España; Dirección General de Conservación de la Naturaleza-Asociación Herpetológica Española (2a Impresión): Madrid, Spain, 2002.

8. Vries, W.D.; Marco, A.; Menor, A. Distribución y diversidad de anfibios en la Sierra Norte de Sevilla. Bol. Asoc. Herpetol. Esp. 2009, $20,74-79$.

9. Rodríguez-Rodríguez, E.J.; Carmona-González, R.; García-Cardenete, L. Actualización de la distribución de los reptiles en la provincia de Sevilla. Bol. Assoc. Herpetol. Esp. 2018, 29, 46-53.

10. Salvador, A.; Pleguezuelos, J.M.; Reques, R. Guía de los Anfibios y Reptiles de España; Asociación Herpetológica Española: Madrid, Spain, 2021.

11. Scheele, B.C.; Hunter, D.A.; Grogan, L.F.; Berger, L.E.E.; Kolby, J.E.; McFadden, M.S.; Marantelli, G.; Skerratt, L.F.; Driscoll, D.A. Interventions for reducing extinction risk in chytridiomycosis-threatened amphibians. Conserv. Biol. 2014, 28, 1195-1205. [CrossRef] [PubMed]

12. AHE. Base de Datos de Anfibios y Reptiles de España. Asociación Herpetológica Española. 2016. Available online: http://siare. herpetologica.es (accessed on 20 October 2021).

13. QGIS Development Team. QGIS Geographic Information System. Open Source Geospatial Foundation Project. 2021. Available online: http:/ / qgis.osgeo.org (accessed on 28 October 2021).

14. Jiménez, J.J.; Romero, D.; Segura, J.; Moreno-Benítez, J.M.; Ripoll, J.J.; García-Cardenete, L. Revisión y actualización de la distribución de los anfibios y reptiles en la provincia de Málaga. Zoology 2016, 108, 121-130.

15. Fernández-Cardenete, J.R.; Luzón-Ortega, J.M.; Pérez-Contreras, J.; Tierno de Figueroa, J.M. Revisión de la distribución y conservación de los anfibios y reptiles en la provincia de Granada (España). Zool. Baetica 2000, 11, 77-104.

16. Ruso, G.E.; Morrissey, C.A.; Hogan, N.S.; Sheedy, C.; Gallant, M.J.; Jardine, T.D. Detecting amphibians in agricultural landscapes using environmental DNA reveals the importance of wetland condition. Environ. Toxicol. Chem. 2019, 38, 2750-2763. [CrossRef]

17. Beja, P.; Alcazar, R. Conservation of Mediterranean temporary ponds under agricultural intensification: An evaluation using amphibians. Biol. Conserv. 2003, 114, 317-326. [CrossRef]

18. Kilpatrick, A.M.; Briggs, C.J.; Daszak, P. The ecology and impact of chytridiomycosis: An emerging disease of amphibians. Trends Ecol. Evol. 2010, 25, 109-118. [CrossRef] [PubMed]

19. Lesbarrères, D.; Balseiro, A.; Brunner, J.; Chinchar, V.G.; Duffus, A.; Kerby, J.; Miller, D.L.; Robert, J.; Schock, D.M.; Waltzek, T.; et al. Ranavirus: Past, present and future. Biol. Lett. 2012, 8, 481-483. [CrossRef] [PubMed] 